Research

Elsevier Editorial System(tm) for Fisheries

Manuscript Draft

Manuscript Number: FISH8056R1

Title: Assessing the impact of buffer towing on the quality of Northeast Atlantic cod (Gadus morhua) caught with a bottom trawl

Article Type: Research Paper

Keywords: Keywords: Buffer towing; cod; fish quality; bottom trawl

Corresponding Author: Mr. Jesse Brinkhof, MSc.

Corresponding Author's Institution: University of Tromsoe

First Author: Jesse Brinkhof, MSc.

Order of Authors: Jesse Brinkhof, MSc.; Roger B Larsen, MSc; Bent

Herrmann, PhD; Stein H Olsen, PhD

Manuscript Region of Origin: NORWAY 


\section{Assessing the impact of buffer towing on the quality of Northeast 2 Atlantic cod (Gadus morhua) caught with a bottom trawl}

3 Jesse Brinkhof $^{\mathrm{a}^{*}}$, Roger B. Larsen ${ }^{\mathrm{a}}$, Bent Herrmann ${ }^{\mathrm{a}, \mathrm{b}}$, Stein H. Olsen ${ }^{\mathrm{c}}$

$4{ }^{\mathrm{a}}$ The Arctic University of Norway UIT, Hansine Hansens veg 18, 9019 Troms $\varnothing$, Norway

${ }^{\mathrm{b}}$ SINTEF Ocean, Fishing Gear Technology, Willemoesvej 2, 9850 Hirtshals, Denmark

${ }^{c}$ Nofima AS, Muninbakken 9-13, Breivika, P.O. Box 6122, N-9291 Troms $\varnothing$, Norway

7

*Corresponding author, Tel. +47 97662167, Email: jesse.brinkhof@uit.no (J. Brinkhof)

\section{Abstract}

The dense aggregations of Northeast Atlantic cod (Gadus morhua) in the Barents Sea have led to a new fishing practice termed "buffer towing." In this fishery, many trawlers redeploy the trawl directly after taking the catch onboard in an attempt to secure a continuous supply of fish and avoid any unnecessary stops during processing. If the approximate desired amount of fish is caught or exceeded before the catch from the previous haul is processed, the trawl is lifted off the seabed and towed at a given depth at low speed, usually $\sim 1-2$ knots, until the production capacity of the onboard factory is restored. Both researchers and fishermen onboard trawlers believe that buffer towing has a negative impact on fish quality, as indicated by increased frequency of gear marks and dead fish, poorer exsanguination, ecchymosis, skin abrasion, fillet gaping, and fillet redness. However, the effect that buffer towing has on fish quality has not been scientifically evaluated. The aim of this study was to document the effects of buffer towing on fish quality. The quality was assessed using two different indexes, one for whole cod and one for cod fillets. The results proved that buffer towing has a negative impact on fish quality. Specifically, cod subjected to buffer towing, in contrast to direct haulback, had an increased relative probability of $371 \%$ for poor exsanguination and an increased relative probability of $209 \%$ for fillet redness. Furthermore, combining scores of the different quality categories within the indexes (e.g., gear marks, ecchymosis, poor exsanguination, and skin abrasion) proved a significant reduction in the quality of cod subjected to buffer towing.

Keywords: Buffer towing; cod; fish quality; bottom trawl

\section{Introduction}

The current stock of Northeast Atlantic cod (Gadus morhua) is the largest cod stock in the world, and it is the most important fishery in the Barents Sea (Yaragina et al., 2011). About 
$70 \%$ of the annual Northeast Atlantic cod quota is caught with bottom trawls (ICES, 2015). The high abundances and dense aggregations of cod frequently lead to large catches (20-30 metric tons) during short towing times (10-20 min). Although the use of catch sensors can provide an estimate of the approximate amount of catch in the codend, the time from haulback initiation to when the trawl physically is lifted off the seabed takes several minutes, and during this time fish are continuously herded into the trawl mouth. In addition, large numbers of fish can already be inside the front part of the trawl when the catch sensors on the codend are activated. During periods of high fish entry rates, trawlers have reported problems with fish blocking the grid section, and thus entering the codend too slowly for effective catch control (Grimaldo et al., 2014). The grid section, which purpose is to release undersized fish, comprise of a grid with $55 \mathrm{~mm}$ bars spacing, according to the legislations (Sistiaga et al., 2016).

These high and dense abundances of cod in the Barents Sea have led to a widespread practice among Norwegian trawlers called "buffer towing," which is believed to negatively affect the quality of the catch (Norwegian Directorate of Fisheries, 2013; Brinkhof et al., 2017a). Buffer towing is also known as "short-wiring" in the Alaska pollock trawl fishery (Dietrich and Melvin, 2007). In this fishery, many trawlers choose to redeploy the trawl directly after taking the catch onboard in order to secure a continuous supply of fish and avoid unnecessary stops during processing in the factory. However, the approximate desired amount of fish is often caught before the catch from the previous haul has been processed. To avoid excessively large catches, the trawl is lifted from the seabed and towed at a given depth at low speed, usually 1-2 knots, until the production capacity onboard is restored (Fig. 1). However, both researchers and fishermen onboard trawlers claim that this practice has a negative impact on the quality of the catch in the form of increased presence of gear marks and dead fish, poorer exsanguination, ecchymosis, skin abrasion, fillet gaping, and fillet redness. Previous studies have documented a significant reduction in fish quality with increasing towing time (Olsen et al., 2013), exhaustive swimming (Svalheim et al., 2017), and catch size and crowding (Suuronen et al., 2005; Margeirsson et al., 2007; Olsen et al., 2008; Rotabakk et al., 2011; Digre et al., 2017). All of these factors are present during buffer towing. Because cod have a physoclist swim bladder, the rapid decompression that occurs when lifting the trawl off the seabed causes the swim bladder to expand and eventually burst when the reduction in ambient water pressure exceeds $\sim 70 \%$ of the original depth (Midling et al., 2012; Humborstad and 
Mangor-Jensen, 2013). Thus, the depth at which the trawl is positioned during buffer towing could be of major importance for the final quality of the fish.

FIG. 1

From an industry point of view, poor fish quality results in reduced price and thus reduced revenue. It also limits the ability to use the fish in various products. From a management point of view, poor fish quality is believed to increase the risk of illegal dumping and high-grading (Batsleer et al., 2015), subsequently contributing to mortality that is not accounted for in catch records. Hence, poor fish quality is not in accordance with sustainable resource exploitation. Furthermore, Brinkhof et al. (2017a) reported a high escape rate of cod up to at least $42 \mathrm{~cm}$ long from the codend during buffer towing. The survival rate of these escaping cod is unknown, but it is likely lower than the survival rates reported for cod escaping at the seabed (Soldal et al., 1993; Suuronen et al., 1995; Ingólfsson et al., 2007) due to barotrauma related injuries, elevated stress, suffocation, and subsequent increased risk of predation or disease susceptibility (DeAlteris and Reifsteck, 1993; Chopin and Arimoto, 1995; Davis, 2002; Ryer et al., 2004; Humborstad and Mangor-Jensen, 2013; Brinkhof et al., 2017a; Rankin et al., 2017).

This study was conducted to assess the impact of buffer towing on fish quality by investigating the following research questions:

- Is there any difference in quality of whole fish from buffer towed hauls and hauls that are taken directly onboard?

- Is there any difference in fillet quality of fish from buffer towed hauls and hauls that are taken directly onboard?

\section{Materials and methods}

\subsection{Study area and trawl configuration}

The fishing trials were conducted during November 2016 onboard the R/V "Helmer Hanssen" $(63.8 \mathrm{~m}, 4080 \mathrm{HP})$ in the central part of the Barents Sea (N 7459'-N 75² $26^{\prime}$; E $30^{\circ} 54^{\prime}-$ $\left.\mathrm{E} 31^{\circ} 17^{\prime}\right)$. The configuration of the trawl was similar to the setup used in commercial fisheries. A set of Injector otter boards for bottom trawl $\left(3100 \mathrm{~kg}\right.$ and $\left.8 \mathrm{~m}^{2}\right)$ with backstraps were followed by $60 \mathrm{~m}$ long sweeps that were equipped with an $\emptyset 53 \mathrm{~cm}$ steel bobbin in the middle to avoid excessive abrasion of the sweeps. The $46.9 \mathrm{~m}$ long ground gear consisted on both sides of a $14 \mathrm{~m}$ long chain equipped with three steel bobbins $(\varnothing 53 \mathrm{~cm})$ and an $18.9 \mathrm{~m}$ long 
rock-hopper gear in the center composed of $\varnothing 53 \mathrm{~cm}$ rubber discs. The trawl used was a twopanel Alfredo 3 fish trawl built from polyethylene with a $150 \mathrm{~mm}$ nominal mesh size. A size sorting grid with a $55 \mathrm{~mm}$ bar spacing was inserted between the codend and the trawl belly, which is compulsory in the trawl fishery in the Northeast Atlantic (Sistiaga et al., 2016). A four-panel codend (mesh size $132.1 \pm 2.6 \mathrm{~mm}$ (mean \pm standard deviation)) with a 2- to 4transition section was mounted after the grid section.

Catch size is known to affect fish quality. To reduce the variation in catch size between hauls, the amount of fish allowed in the codend was set to approximately 2 metric tons. This was achieved by inserting an excessive fish excluder device (i.e., a release mechanism in the anterior part of the codend) (Grimaldo et al., 2014; Brinkhof et al., 2017a). The excessive fish excluder device comprise of a fish lock with two escape openings in the front. When the codend is filled up to the fish lock, all excessive fish will be released through the escape openings in front of the fish lock (Grimaldo et al., 2014; Brinkhof et al., 2017a).

The trawl was monitored with a set of door sensors, a height sensor, and a catch sensor from Scanmar. In addition, a Scanmar trawl eye was used to control the buffer towing depth.

\subsection{Data sampling}

Directly after taking the catch onboard, 30 cod were randomly sampled from the codend. These fish were immediately killed and exsanguinated in running seawater (ca. 50 1/min) for $30 \mathrm{~min}$. Afterwards the water was drained from the tank and the fish were gutted and decapitated before being frozen at $-30^{\circ} \mathrm{C}$ for further analysis on land. On land, the fish were thawed in tanks containing 10001 of chilled water $\left(1^{\circ} \mathrm{C}\right)$ for $24 \mathrm{~h}$ and then further thawed on ice for an additional $24 \mathrm{~h}$ at $0-1{ }^{\circ} \mathrm{C}$. Once the fish were thawed, they were evaluated for catch-related defects incurred during the catching process using a catch damage index (Table 1) (Rotabakk et al., 2011; Esaiassen et al., 2013; Olsen et al., 2013). The fish were then filleted manually and the black lining (peritoneum) was removed to enable evaluation of the belly flap. Both fillets from each fish were assessed for defects using a fillet index (Table 2) (Olsen et al., 2013, 2014; Svalheim et al., 2017). The assessment fish quality applying the two indexes were done consecutively, i.e. the samples are not traceable between the two indexes. In addition to the fillet index, the number of severe bleedings in the posterior dorsal side muscle of the abdominal cavity caused by the rupture of the swim bladder during the ascent was counted. The assessment of catch damage and fillet quality was performed as a blinded experiment, i.e. the evaluators were unaware if the fish came from a regular tow or a buffer 
126

131 We wanted to determine if there was any difference in the probability between the hauls with 132 and without buffer towing for cod to obtain a specific catch damage score and fillet quality 133 score. For each index the score on a specific category was either 0, 1, 2, or 3 (Tables 1 and 2). 134 A high score indicates severe damage (i.e., low fish quality). Analyses of the obtained scores 135 from the catch damage index and fillet index were carried out separately, following the 136

$$
\begin{gathered}
\widehat{p_{a s}}=\frac{\sum_{j=1}^{m}\left\{\frac{1}{n_{j}} \sum_{t=1}^{n_{j}} \operatorname{equal}\left(s, k_{a j t}\right)\right\}}{w^{m}} \\
\text { with } \\
\operatorname{equal}(s, k)=\left\{\begin{array}{l}
1 \forall k=s \\
0 \forall k \neq s
\end{array}\right.
\end{gathered}
$$

140 where $m$ is the number of hauls conducted with either buffer towing or regular towing with 141 direct haul-back; $n_{j}$ is the number of fish given a score in haul $j ; k_{a j t}$ is the score given in 142 category $a$ to fish or fillet number $t$ evaluated in haul $j$.

143 Equation (1) was used to estimate the probability of obtaining a given score $s$ in category $a$ 144 according to the catch damage index and the fillet index for the two different towing types 145 separately. We also estimated the probability $\widehat{p m_{a s}}$ for obtaining a score that did not exceed $s$ 146 on category $a$ (i.e., the probability of obtaining a given score or lower):

$$
\begin{gathered}
\widehat{p m_{a s}}=\frac{\sum_{j=1}^{m}\left\{\frac{1}{n_{j}} \Sigma_{t=1}^{n_{j}} \text { lequal }\left(s, k_{a j t}\right)\right\}}{m} \\
\text { with } \begin{array}{c}
m \\
\text { lequal }(s, k)=\left\{\begin{array}{l}
1 \forall k \leq s \\
0 \forall k>s
\end{array}\right.
\end{array}
\end{gathered}
$$

148 Equations (1) and (2) provide an evaluation of each category separately. However, we also 149 investigated the probability for a fish to score $\mathrm{s}$ or maximum $\mathrm{s}$ on two or more of the 150 categories simultaneously. To estimate such probabilities we extended (1) and (2) as follows: 


$$
\widehat{p_{a s} p_{b s}}=\frac{\sum_{j=1}^{m}\left\{\frac{1}{n_{j}} \sum_{t=1}^{n_{j}} \operatorname{equal}\left(s, k_{a j t}\right) \times \operatorname{equal}\left(s, k_{b j t}\right)\right\}}{m}
$$

$$
\begin{gathered}
p_{a s} \widehat{p_{b s}} p_{c s}=\frac{\sum_{j=1}^{m}\left\{\frac{1}{n_{j}} \sum_{t=1}^{n_{j}} \text { equal }\left(s, k_{a j t}\right) \times \operatorname{equal}\left(s, k_{b j t}\right) \times \operatorname{equal}\left(s, k_{c j t}\right)\right\}}{m} \\
p_{a s} \widehat{p_{b s} p_{c s}} p_{d s}=\frac{\sum_{j=1}^{m}\left\{\frac{1}{n_{j}} \sum_{t=1}^{n_{j}} \operatorname{equal}\left(s, k_{a j t}\right) \times \operatorname{equal}\left(s, k_{b j t}\right) \times \operatorname{equal}\left(s, k_{c j t}\right) \times \operatorname{equal}\left(s, k_{d j t}\right)\right\}}{m}
\end{gathered}
$$

and

$$
p \widetilde{m a s} \widehat{p m}_{b s}=\frac{\sum_{j=1}^{m}\left\{\frac{1}{n_{j}} \sum_{t=1}^{n_{j}} \text { lequal }\left(s, k_{a j t}\right) \times \text { lequal }\left(s, k_{b j t}\right)\right\}}{m}
$$

$$
\begin{gathered}
p m_{a s} \widehat{p m_{b s}} p m_{c s}=\frac{\sum_{j=1}^{m}\left\{\frac{1}{n_{j}} \sum_{t=1}^{n_{j}} \text { lequal }\left(s, k_{\text {ajt }}\right) \times \operatorname{lequal}\left(s, k_{b j t}\right) \times \operatorname{lequal}\left(s, k_{c j t}\right)\right\}}{m} \\
p m_{a s} p \widehat{m}_{b s} p m_{c s} p m_{d s}=\frac{\sum_{j=1}^{m}\left\{\frac{1}{n_{j}} \sum_{t=1}^{n_{j}} \text { lequal }\left(s, k_{a j t}\right) \times \operatorname{lequal}\left(s, k_{b j t}\right) \times \operatorname{lequal}\left(s, k_{c j t}\right) \times \operatorname{lequal}\left(s, k_{d j t}\right)\right\}}{m}
\end{gathered}
$$

154 Equations (3) and (4) were applied for all possible combinations of the categories.

155 Estimation of the uncertainties in the expected values for the probability parameters 156 calculated based on (1)-(4) required consideration of several aspects: i) the average score may 157 vary between hauls with the same type of fishing process (regular or buffer tow) due to 158 uncontrolled effects in the fishing process; ii) the average score for the individual hauls is 159 subjected to within-haul variability because a limited sample of fish is evaluated in each haul; 160 iii) there may be correlation between the probability for the scores between categories, which complicates the estimations of uncertainties for the combined probabilities (3) and (4).

162 To account correctly for these uncertainties in the estimations, a double bootstrap method was 163 adapted that is well established for evaluating fishing gear selectivity and catch efficiency for 164 trawl fisheries that are known to be subjected to a similar structure of uncertainty (Wienbeck et al., 2014; Brinkhof et al., 2017ab). The procedure accounted for between-haul variation in the obtained scores by selecting $m$ hauls with replacement from the pool of hauls of the specific haul type (i.e., regular or buffer tow) during each bootstrap repetition. Within-haul uncertainty in the obtained scores was accounted for by randomly selecting fish or fillets with replacement from the selected haul. The number of fish or fillets selected from each haul was the same as the number of fish or fillets evaluated for that haul $\left(n_{j}\right)$. The resulting data for each bootstrap were then used to estimate the expected category probabilities based on equations (1)-(4). We performed 1000 bootstrap repetitions and calculated the Efron 95\% percentile confidence limits (Efron, 1982) for the estimated probabilities. 
174 The difference in fish quality between regular hauls with direct haul-back and those with

175 buffer towing could in principle be inferred by pairwise comparison of $95 \%$ confidence 176 intervals (CIs) for the category probabilities (1)-(4) that are estimated for the two types of 177 towing separately. In cases for which the CIs did not overlap it could be concluded that buffer 178 towing would have a significant effect on the parameter(s) compared. However, we also can 179 consider the situation as a two-sample problem (Moore et al., 2003) with two independent 180 samples, for which the results for the regular hauls represent one of the samples and the 181 results for the buffer towing hauls the other. Based on this we can use the 1000 bootstrap 182 results for an arbitrary parameter $r$ (one based on (1) to (4)) for regular hauling $r_{\text {base }}$ and buffer 183 towing $r_{\text {buffer }}$ to obtain a bootstrap population with 1000 results for the difference:

where $i$ denotes the bootstrap repetition index. Because sampling was random and independent for the two groups of results (regular and buffer tows), it is valid to generate the bootstrap population of results for the difference based on (5) using the two independent generated bootstrap files (Moore et al., 2003). Based on the bootstrap population we can obtain Efron $95 \%$ percentile confidence limits for $\Delta r$ as described above. If the CI for $\Delta r$ does not contain 0.0, we can conclude that buffer towing has a significant effect on the value of parameter $r$. In general, the CI for $\Delta r$ cannot exceed what is spanned by $r_{b a s e}$ and $r_{b u f f e r}$ together and will often be smaller (Moore et al., 2003). Therefore, using this approach will increase the power of inference of the effect of buffer towing compared to the simple strategy based on the search for non-overlapping CIs for the separate parameter values. Following the strategy for $\Delta r$ we can also obtain a bootstrap population for the relative percentage effect of buffer towing by:

$\operatorname{relr}_{i}=\frac{r_{\text {buffer }_{i}}-r_{\text {base }_{i}}}{r_{\text {base }_{i}}} \times 100 i \in[1 \ldots 1000]$

We used (6) to obtain Efron 95\% percentile confidence limits for the relative differences in the parameter values between regular towing and buffer towing.

The estimation procedures described above were implemented in the analysis tool SELNET (Herrmann et al., 2012). The results were exported for graphical presentation in R (R Core Team, 2013).

\section{Results}


204 During the cruise 20 hauls were conducted alternating between regular haul-back and buffer

205 towing (Table 3). From each tow $30 \mathrm{cod}$ were randomly sampled from the codend on deck 206 directly after the catch was hauled onboard. This resulted in $600 \mathrm{cod}$ for the assessment of 207 catch quality, 300 cod subjected to buffer towing, and 300 cod haul-back directly. The towing 208 time was restricted to a maximum of $2 \mathrm{~h}$ at the seabed and $1 \mathrm{~h}$ of buffer towing. The catch 209 restriction device ensured that each haul contained approximately 2 tons of cod. The towing 210 depth during buffer towing was controlled by the trawl eye to ensure that the trawl was kept at 211 a depth that was approximately $40 \%$ of the fishing depth (Table 3, Fig. 1).

\section{TABLE 3}

213 Figure 2 shows the frequency of the different scores for the catch damage index for the hauls 214 with regular haul-back, and Figure 3 shows the frequency of the scores for the hauls that were 215 buffer towed.

216 FIG. 2

217 FIG. 3

218 Figure 4 shows the frequency of the different scores for the fillet index for the hauls with regular haul-back, and Figure 5 shows the frequency of the scores for the hauls that were buffer towed.

FIG. 4

\section{FIG. 5}

223 Figures 6-9 show the probability for cod that were either buffer towed or hauled-back directly 224 to obtain a score from 0 to 3. A high probability of obtaining a score of 0 or 1 indicates good 225 quality and thus little damage. In contrast, a high probability of obtaining a score of 2 or 3 226 indicates poor quality and a high degree of damage. Nearly all estimated probabilities show a 227 reduction in the quality of cod exposed to buffer towing. However, differences in fish quality are only deemed significant in cases where the CIs from the relative difference in probabilities calculated by applying the two sample bootstrapping method described in section 2.3 do not contain the value 0.0 .

231 Figure 6 compares results for quality assessed by applying the catch damage index for each 232 single category between the regular tows and the hauls that were buffer towed. Cod that were buffer towed had a significantly higher probability of obtaining a score of 2 for the category 
234 "poor exsanguination", whereas the probability of getting a score of 0 and $\leq 1$ was 235 significantly higher for cod that were hauled back directly (i.e., good exsanguination) (Fig. 6, 236 Table 4). Table 4 presents all estimated probabilities with 95\% CI that exhibited a significant 237 difference in the probability of obtaining a given score between regular towing and buffer 238 towing. Applying two sample bootstrapping enabled the calculation of the relative differences 239 in probability. A negative relative probability value indicates a significant reduction in the 240 probability of obtaining a given score when buffer towing and vice versa. Thus, a negative 241 relative probability value for score 0 or $\leq 1$ means a reduction in the probability of obtaining 242 these scores for fish subjected to buffer towing, whereas a positive relative probability value 243 for score 2 means increased probability of obtaining this score for fish subjected to buffer 244 towing. Because scores of 0 and 1 are equivalent to "flawless" and "slightly" and scores of 2 245 and 3 are equivalent to "moderate" and "severe", all results in Table 4 prove a significant 246 reduction in the quality of fish subjected to buffer towing. Specifically, the probability of 247 achieving a score of 2 for regular haul-back was $2 \%$ compared to $11 \%$ for buffer towing, 248 which resulted in a $371 \%$ increase in the relative probability of poor exsanguination (Table. $2494)$.

$250 \quad$ FIG. 6

251 Comparing the results from the catch damage index for all categories combined proved 252 significantly better quality for cod for the regular hauls with direct haul-back compared to 253 buffer towed hauls, i.e. increased probability of obtaining a score of 0 and $\leq 1$ (Fig. 7). 254 Moreover, comparing the results for all possible combinations of two categories proved a 255 significant reduction in the quality of buffer towed cod for the following category 256 combinations: "ecchymosis and exsanguination", "exsanguination and skin abrasion", 257 "ecchymosis and gear marks", and "exsanguination and gear marks" (Fig. 7, Table 4).

\section{$258 \quad$ FIG. 7}

259 For the following combinations of three categories, ("ecchymosis, gear marks, and 260 exsanguination", “exsanguination, ecchymosis, and skin abrasion”, “ecchymosis, gear marks, 261 and skin abrasion", and "ecchymosis, exsanguination, and skin abrasion"), the estimated 262 probabilities proved a significant reduction in the quality of cod that were buffer towed (Fig. 263 8, Table 4).

264 FIG. 8 
265 Figure 9 shows the estimated probabilities for obtaining a given score according to the fillet 266 index for the regular tows and the hauls that were buffer towed. Cod that were buffer towed had a significantly higher probability of obtaining a score of 2 for the category "discoloration", whereas the probability of obtaining a score of 0 and $\leq 1$ was significantly higher for cod that were hauled-back regularly (Fig. 9, Table 4). Specifically, the probability of achieving a score of 2 for regular haul-back was $4 \%$ compared to $13 \%$ for buffer towing, which resulted in a $209 \%$ increase in the relative probability of obtaining a high score, i.e.

272 high degree of fillet redness (Table 4). Furthermore, the probability of achieving score of 0 for 273 regular haul-back was $34 \%$ compared to $17 \%$ for buffer towing, which resulted in a $52 \%$ decrease in the relative probability of achieving a score 0 for the degree of fillet whiteness (Table 4). Also, for the score $\leq 1$, buffer towing proved a significant reduction in the quality, i.e. increased fillet redness (Fig. 9, Table 4). The two fillets shown in the left panel of Figure 10a represent a typical example of score 0 for the category "discoloration", whereas the two fillets on the right were given a score of 2 . Figure 10b shows a typical example of fillet 279 gaping.

FIG. 9

FIG. 10

\section{TABLE 4}

283 The significant differences in the category "discoloration" from the fillet index for the hauls 284 that were buffer towed (i.e., increased fillet redness) (Fig. 9, Table 4) are corroborated by the 285 results from the catch damage index that proved a significantly poorer exsanguination for cod 286 that were buffer towed (Fig. 6, Table 4).

\section{Discussion}

288 Results of this study proves that buffer towing negatively affects the quality of cod. Cod subjected to buffer towing exhibited a significantly increased probability of poor exsanguination, which was further reflected in the increased redness of the fillets.

291 Specifically, the results demonstrated a 371\% increased relative probability of poor exsanguination and a $209 \%$ increase in relative probability of fillet redness for cod subjected

293 to buffer towing. In addition, considering the combined impact of two or three categories 294 simultaneously within the catch damage index, proved a significant reduction in quality for 295 buffer towed cod for scores within 10 out of 12 possible combinations. Investigating the 
probability of obtaining a given score for all categories simultaneously also proved a 297 significant probability that buffer towed cod would obtain a higher score (i.e., reduced quality). For the scores from the fillet index, only the category "discoloration" was significantly poorer, (i.e. increased redness) for cod subjected to buffer towing compared to direct haul-back. The results for the categories "surface consistency" and "fillet texture" were approximately equal between buffer towed cod and cod hauled-back directly, which was expected because these two categories are mainly affected by storage of fish.

The results presented in this study are likely to be conservative due to small catch size ( 2 tons) and short towing time. In the commercial fishery catch sizes often exceed 10 tons, and towing times can be up to 7 hours. Skippers usually delay the decision to buffer tow, and combined with the difficulty of judging the density of the fish entering the trawl according to the echogram and the catch sensors on the codend, buffer towing entails additional time in the water as well as large catches. Previous studies have reported that increased catch size and towing time negatively affect fish quality (Olsen et al., 2013; Digre et al., 2017; Svalheim et al., 2017), and Olsen et al. (2008) reported that crowding of fish in the codend has a negative effect on fish quality, especially the degree of exsanguination and fillet discoloration. Besides, the time from catch to processing has a significant impact on the final quality of fish

313 (Margeirsson et al., 2007). Since buffer towing entails prolonged time from catch to 314 processing under conditions which are known to negatively affect catch quality, it is highly 315 likely that the duration of buffer towing has an impact on the fish quality. Furthermore, previous studies report that the bursting of swim bladder results in the evacuation of gas through an intraperitoneal path to the anal area (Midling et al., 2012; Humborstad and Magnor-Jensen, 2013). However, underwater video recordings have shown that the dense packing of cod in the codend prohibits cod from turning belly up when the swim bladder is overinflated, which results in the gas remaining trapped within the dorsal side of the abdominal cavity when the swim bladder ruptures near the pin bones during buffer towing, causing severe bleeding. Thus, we speculate that in addition to buffer towing duration, also the depth to where the trawl is lifted during buffer towing could impact the quality of fish catches. Furthermore, fishermen frequently claim increased amounts of dead fish in catches subjected to buffer towing, especially for long buffer towing with large catches. This is likely caused by the dense packing of fish in the codend, which prohibits the fish from moving their operculum, resulting in suffocation; it also reduces fish quality due to insufficient exsanguination (Olsen et al., 2014). 
This study presents a method for analyzing scores based on the catch damage index and fillet index. It provides results with a specific probability with $95 \%$ confidence limits. This method also provides conservative estimates of the probability, as it takes into account uncontrolled effects between each measurement within each haul as well as the variation between hauls.

All categories within the catch damage index and the fillet index are indicative of the quality of the catch. Although many studies document the importance of correct processing procedures of caught fish, it is impossible to improve fish quality if it is already reduced during the catching process, as is the case with buffer towing. The consequences of poor fish quality include reduced revenue and limited applicability of the fish for various products. High end markets demand good quality fish. Moreover, poor fish quality is thought to increase the risk of dumping and high-grading (Batsleer et al., 2015). Another negative consequence of buffer towing is the high escape rate of cod during that towing phase, where the probability of survival of escaped fish is believed to be reduced (Brinkhof et al., 2017a). Based on the results presented in this study, which proves a significant reduction in the quality of cod subjected to buffer towing, as well as the documented escape rate from the codend (Brinkhof et al., 2017a), buffer towing should be avoided.

\section{Acknowledgments}

The Norwegian Research Council (Grant No. 203477) funded this study through the project "Centre of Research-based Innovation in Sustainable Fish Capture and Processing Technology (CRISP)". We are grateful for the effort and comments from the editor and the anonymous reviewers. We thank the Norwegian Directorate of Fisheries for the necessary permits and the Arctic University of Norway for financial support. We also thank Manu Sistiaga, Ivan Tatone, and Jure Brčić for help provided during the cruise and Torbjørn Tobiassen, Sjurdur Joensen, and Tatiana Ageeva for help during the quality assessment on land.

\section{References}

Batsleer, J., Hamon, K.G., van Overzee, H.M.J., Rijnsdorp, A.D., Poos, J.J., 2015. Highgrading and over-quota discarding in mixed fisheries. Rev. Fish Biol. Fish. 25, 715-736. doi:10.1007/s11160-015-9403-0 
Brinkhof, J., Herrmann, B., Larsen, R.B., Sistiaga, M., 2017a. Escape rate for cod (Gadus morhua) from the codend during buffer towing. ICES Journal of Marine Science https://doi.org/10.1093/icesjms/fsx200

Brinkhof. J. Larsen, R.B., Herrmann, B., Grimaldo, E., 2017b. Improving catch efficiency by changing ground gear design: Case study of Northeast Atlantic cod (Gadus morhua) in the Barents Sea bottom trawl fishery. Fisheries Research 186: 269-282, https://doi.org/10.1016/j.fishres.2016.10.008

Chopin, F.S., Arimoto, T., 1995. The condition of fish escaping from fishing gears-a review. Fish. Res. 21 (3-4), 315-327 http://dx.doi.org/10.1016/0165-7836(94)00301-C.

Davis, M. W., 2002. Key principles for understanding fish bycatch discard mortality. Canadian Journal of Fisheries and Aquatic Sciences, 59(11), 1834-1843, DOI: 10.1139/F02-139

DeAlteris, J. T., Reifsteck, D.M., 1993. Escapement and survival of fish from the codend of a demersal trawl. ICES Mar. Sci. Symp., 196: 128-131.

Dietrich, K.S., Melvin, E. F., 2007. Alaska Trawl Fisheries: Potential Interactions with North Pacific Albatrosses. WSG-TR 07-01, Washington Sea Grant, Seattle, WA

Digre, H., Rosten, C., Erikson, U., Mathiassen, J.R., Aursand, I.G., 2017. The on-board live storage of Atlantic cod (Gadus morhua) and haddock (Melanogrammus aeglefinus) caught by trawl: Fish behaviour, stress and fillet quality. Fish. Res. 189, 42-54.

Efron, B., 1982. The jackknife, the bootstrap and other resampling plans. SIAM Monograph No. 38, CBSM-NSF.

Esaiassen, M., Akse, L. and Joensen, S., 2013. Development of a catch-damage-index to assess the quality of cod at landing. Food Control, 29(1), pp.231-235.0254-2. Doi: http://dx.doi.org/10.1016/j.foodcont.2012.05.065

Grimaldo, E., Sistiaga, M., Larsen, R. B., 2014. Development of catch control devices in the Barents Sea cod fishery. Fisheries Research, 155, 122-126, https://doi.org/10.1016/j.fishres.2014.02.035

ICES, 2015. Report of the Arctic Fisheries Working Group (AFWG), 2015, Hamburg, Germany. ICES CM 2015/ACOM: 05, 639 pp. 
Ingólfsson, Ó. A., Soldal, A. V., Huse, I., Breen, M., 2007. Escape mortality of cod, saithe, and haddock in a Barents Sea trawl fishery. ICES Journal of Marine Science: Journal du Conseil, 64(9), 1836-1844. doi: 10.1093/icesjms/fsm150

Herrmann, B., Sistiaga, M., Nielsen, K.N., Larsen, R.B. 2012. Understanding the size selectivity of redfish (Sebastes spp.) in North Atlantic trawl codends. Journal of Northwest Atlantic Fishery Science 44, 1-13.

Humborstad, O-D., Mangor-Jensen, A., 2013. Buoyancy adjustment after swimbladder puncture in cod Gadus morhua: An experimental study on the effect of rapid decompression in capture-based aquaculture. Marine Biology Research, 9:4, 383-393, DOI: $10.1080 / 17451000.2012 .742546$

Margeirsson, S., Jonsson, G. R., Arason, S., Thorkelsson, G., 2007. Influencing factors on yield, gaping, bruises and nematodes in cod (Gadus morhua) fillets. Journal of Food and Engineering, 80: 503-508, https://doi.org/10.1016/j.jfoodeng.2006.05.032

Midling, K. Ø., Koren, C., Humborstad, O. B., Sæther, B. S., 2012. Swimbladder healing in Atlantic cod (Gadus morhua), after decompression and rupture in capture-based aquaculture. Marine Biology Research, 8(4), 373-379.

Moore, D.S, McCabe, G.P., Duckworth, W.M., Sclove, S.L, 2003. Practice of Business Statistics using data for decisions. Published by W. H. Freeman. ISBN 10: 0716757230 / ISBN 13: 9780716757238.

Olsen, S. H., Joensen, S., Tobiassen, T., Heia, K., Akse, L., Nilsen, H., 2014. Quality consequences of bleeding fish after capture. Fisheries Research 153, 103-107. http://dx.doi.org/10.1016/j.fishres.2014.01.011

Olsen, S. H., Sørensen, N. K., Larsen, R., Elvevoll, E. O., Nilsen, H., 2008. Impact of preslaughter stress on residual blood in fillet portions of farmed Atlantic cod (Gadus morhua) — measured chemically and by visible and near-infrared spectroscopy. Aquaculture, 284(1), 90-97

Olsen, S. H., Tobiassen, T., Akse, L., Evensen, T.H., Midling, K.Ø., 2013. Capture induced stress and live storage of Atlantic cod (Gadus morhua) caught by trawl: Consequences for the flesh quality. Fisheries Research 147, 446-453. http://dx.doi.org/10.1016/j.fishres.2013.03.009 
R Core Team, 2013. R: A language and environment for statistical computing. R Foundation for Statistical Computing, Vienna, Austria. URL http://www.R-project.org/

Rankin, P. S., Hannah, R. W., Blume, M. T., Miller-Morgan, T. J., Heidel, J. R., 2017. Delayed effects of capture-induced barotrauma on physical condition and behavioral competency of recompressed yelloweye rockfish, Sebastes ruberrimus. Fish. Res., 186, 258-268. http://dx.doi.org/10.1016/j.fishres.2016.09.004

Rotabakk, B. T., Skipnes, D., Akse, L., Birkeland, S., 2011. Quality assessment of Atlantic cod (Gadus morhua) caught by longlining and trawling at the same time and location. Fish. Res. 112, 44-51. doi:10.1016/j.fishres.2011.08.009

Ryer, C. H., Ottmar, M. L., Sturm, E. A., 2004. Behavioral impairment after escape from trawl codends may not be limited to fragile fish species. Fisheries Research, 66: 261269. doi:10.1016/S0165-7836(03)00197-8

Sistiaga, M., Brinkhof, J., Herrmann, B., Grimaldo, Langård, L., Lilleng, D., 2016. Size selection performance of two flexible sorting grid section designs in the Northeast Arctic cod (Gadus morhua) and haddock (Melanogrammus aeglefinnus) fishery Fisheries Research, 183: 340-351.

Soldal, A. V., Engås, A., Isaksen, B., 1993. Survival of gadoids that escape from a demersal trawl. ICES mar. Sci. Symp., 196: 122-127

Suuronen, P., Lehtonen, E., Jounela, P., 2005. Escape mortality of trawl caught Baltic cod (Gadus morhua) - the effect of water temperature, fish size and codend catch. Fisheries research, 71(2), 151-163. http://dx.doi.org/10.1016/j.fishres.2004.08.022

Suuronen, P., Lehtonen, E., Tschernij, V., Larsson, P. Q., 1995. Skin injury and mortality of Baltic cod escaping from trawl codends equipped with exit windows. ICES CM 1995/B:8 Fish Capture Committee.

Svalheim, R. A., Karlsson-Drangsholt, A., Olsen, S. H., Johnsen, H. K., Aas-Hansen, Ø., 2017. Effects of exhaustive swimming and subsequent recuperation on flesh quality in unstressed Atlantic cod. Fisheries Research 193: 158-163, https://doi.org/10.1016/j.fishres.2017.04.008

Yaragina, N. A., Aglen, A., Sokolov, K. M., 2011. 5.4 Cod, in: Jakobsen, T., Ožigin, V. K., (Eds.). The Barents Sea: ecosystem, resources, management: half a century of Russian-Norwegian cooperation. Trondheim: Tapir Academic Press, pp. 225-270. 
448 Wienbeck, H., Herrmann, B., Feekings, J.P., Stepputtis, D., Moderhak, W., 2014. 449 Comparative analysis of legislated and modified Baltic Sea trawl codends for 450 simultaneously improving the size selection of cod (Gadus morhua) and plaice 451 (Pleuronectes platessa). Fisheries Research 150: 28-37. 
1 Table 1. The catch damage index used to assess the quality of the fish caught.

2 Table 2. The fillet index used to assess the quality of the fillets.

3 Table 3. Overview of the hauls conducted showing the towing start time and towing time,

4 haul type, depth, average buffer towing depth with the standard deviation in parenthesis, and

5 the percentage depth reduction during buffer towing.

6 Table 4. The probability estimation with $95 \% \mathrm{CI}$ in parenthesis for the scores according to the

7 different categories that proved a significant difference in terms of catch damage between

8 regular towing and buffer towing. The relative differences in the probability for a given score

9 presented in the right column were calculated by applying the two sample bootstrapping

10 method implemented in SELNET.

11

12

13

14

15

16

17

18

19

20

21 


\begin{tabular}{|c|c|c|c|c|c|}
\hline \multirow[b]{2}{*}{ Catch damage } & \multicolumn{4}{|c|}{ Score } & \multirow[b]{2}{*}{ Description } \\
\hline & Flawless & Slightly & Moderate & Severe & \\
\hline Poor exsanguination & 0 & 1 & 2 & 3 & Improper bleeding, blood in veins \\
\hline Ecchymosis & 0 & 1 & 2 & 3 & Discoloration on the skin, bruises \\
\hline Gear marks & 0 & 1 & 2 & 3 & Marks on the skin caused by gear contact \\
\hline Skin abrasion & 0 & 1 & 2 & 3 & Loss of scales \\
\hline
\end{tabular}

Table 2

\section{Score}

Fillet quality Flawless Slightly Moderate Severe

\begin{tabular}{llllll}
\hline Gaping & 0 & 1 & 2 & 3 & Gaping of fillet, disintegration \\
Discoloration & 0 & 1 & 2 & 3 & Fillet redness from white, pinkish, to reddish \\
Texture & 0 & 1 & 2 & 3 & Disintegration of fillet surface \\
Consistency & 0 & 1 & 2 & 3 & Fillet softness, firmness \\
\hline
\end{tabular}

Table 3

\begin{tabular}{ccccccc}
\hline Haul no. & $\begin{array}{c}\text { Time start } \\
(\mathbf{U T C})\end{array}$ & $\begin{array}{c}\text { Towing time } \\
(\mathbf{m} \boldsymbol{\text { min}})\end{array}$ & $\begin{array}{c}\text { Buffer } \\
\text { towing }\end{array}$ & $\begin{array}{c}\text { Depth } \\
(\mathbf{m})\end{array}$ & $\begin{array}{c}\text { Mean buffer } \\
\text { towing depth (m) }\end{array}$ & $\begin{array}{c}\text { Depth } \\
\text { reduction (\%) }\end{array}$ \\
\hline 1 & $16: 48$ & 130 & No & 365.5 & - & - \\
2 & $00: 53$ & 196 & Yes & 374.1 & $216.9(4.0)$ & 42.0 \\
3 & $04: 54$ & 108 & No & 367.4 & - & - \\
4 & $07: 29$ & 193 & Yes & 372.8 & $208.9(3.3)$ & 44.0 \\
5 & $12: 00$ & 120 & No & 362.7 & - & - \\
6 & $15: 00$ & 145 & Yes & 372.0 & $212.8(4.0)$ & 42.8 \\
7 & $20: 46$ & 114 & No & 372.7 & - & - \\
8 & $00: 43$ & 193 & Yes & 360.4 & $225.2(6.5)$ & 37.5 \\
9 & $04: 49$ & 120 & No & 368.3 & - & - \\
10 & $12: 53$ & 192 & Yes & 368.6 & $210.4(5.4)$ & 42.9 \\
11 & $17: 00$ & 90 & No & 365.5 & - & - \\
12 & $19: 29$ & 168 & Yes & 361.7 & $209.2(5.8)$ & 42.2 \\
13 & $23: 01$ & 100 & No & 359.3 & - & - \\
14 & $01: 26$ & 175 & Yes & 358.8 & $217.7(4.4)$ & 39.3 \\
15 & $08: 12$ & 133 & No & 341.8 & - & - \\
16 & $13: 31$ & 192 & Yes & 335.1 & $195.1(5.1)$ & 41.8 \\
17 & $17: 09$ & 120 & No & 347.9 & - & - \\
18 & $20: 06$ & 195 & Yes & 341.9 & $205.1(5.9)$ & 40.0 \\
19 & $00: 00$ & 120 & No & 351.1 & - & - \\
20 & $03: 13$ & 199 & Yes & 354.3 & $192.0(3.8)$ & 45.8 \\
\hline
\end{tabular}




\begin{tabular}{|c|c|c|c|c|c|}
\hline Catch damage index & Score & $\begin{array}{l}\text { Probability for } \\
\text { score in regular } \\
\text { tow }\end{array}$ & $\begin{array}{l}\text { Probability for } \\
\text { score in buffer } \\
\text { tow }\end{array}$ & $\begin{array}{c}\text { Differences in score } \\
\text { probability }\end{array}$ & $\begin{array}{c}\text { Relative differences in } \\
\text { score probability (\%) }\end{array}$ \\
\hline \multirow{3}{*}{ Poor exsanguination } & $=0$ & $0.46(0.33-0.58)$ & $0.30(0.21-0.39)$ & $-0.16(-0.32--0.004)$ & $-35.22(-61.71--2.89)$ \\
\hline & $=2$ & $0.02(0.00-0.04)$ & $0.11(0.06-0.17)$ & $0.09(0.03-0.15)$ & $371.43(60.48-2082.92)$ \\
\hline & $\leq 1$ & $0.98(0.96-1.00)$ & $0.89(0.83-0.94)$ & $-0.09(-0.15--0.03)$ & $-9.19(-16.84--4.67)$ \\
\hline \multirow{2}{*}{ All categories combined } & $=0$ & $0.21(0.09-0.33)$ & $0.07(0.03-0.12)$ & $-0.13(-0.26--0.02)$ & $-65.48(-86.44--16.16)$ \\
\hline & $\leq 1$ & $0.88(0.82-0.94)$ & $0.73(0.65-0.81)$ & $-0.15(0.26--0.05)$ & $-17.08(-29.67--6.44)$ \\
\hline Ecchymosis \& poor exsanguination & $\leq 1$ & $0.90(0.84-0.95)$ & $0.76(0.68-0.83)$ & $-0.13(-0.23-0.05)$ & $-15.24(-25.35--6.67)$ \\
\hline Poor exsanguination \& skin abrasion & $\leq 1$ & $0.96(0.92-0.99)$ & $0.87(0.81-0.92)$ & $-0.09(-0.16--0.03)$ & $-10.69(-16.00--3.28)$ \\
\hline \multirow{2}{*}{ Ecchymosis \& gear marks } & $=0$ & $0.41(0.28-0.54)$ & $0.21(0.15-0.27)$ & $-0.20(-0.33-0.07)$ & $-48.03(-68.56--22.73)$ \\
\hline & $\leq 1$ & $0.90(0.84-0.95)$ & $0.80(0.72-0.86)$ & $-0.10(-0.19--0.02)$ & $-12.97(-21.59--2.05)$ \\
\hline \multirow{2}{*}{ Poor exsanguination \& gear marks } & $=0$ & $0.34(0.25-0.45)$ & $0.17(0.10-0.23)$ & $-0.18(-0.29--0.60)$ & $-52.54(-72.40--24.72)$ \\
\hline & $\leq 1$ & $0.96(0.93-0.99)$ & $0.85(0.78-0.92)$ & $-0.11(-0.20--0.04)$ & $-12.66(-21.54--4.18)$ \\
\hline \multirow{2}{*}{ Poor exsanguination, ecchymosis, \& gear marks } & $=0$ & $0.25(0.15-0.36)$ & $0.09(0.05-0.14)$ & $-0.16(-0.29--0.05)$ & $-64.84(-83.58--30.37)$ \\
\hline & $\leq 1$ & $0.89(0.84-0.94)$ & $0.74(0.66-0.82)$ & $-0.15(-0.25--0.06)$ & $-17.27(-28.76--7.39)$ \\
\hline \multirow{2}{*}{ Poor exsanguination, gear marks, \& skin abrasion } & $=0$ & $0.27(0.17-0.38)$ & $0.12(0.06-0.17)$ & $-0.16(-0.28-0.04)$ & $-58.68(-82.75--23.19)$ \\
\hline & $\leq 1$ & $0.95(0.91-0.99)$ & $0.84(0.76-0.91)$ & $-0.11(-0.19--0.03)$ & $-12.81(-21.72--3.10)$ \\
\hline \multirow{2}{*}{ Ecchymosis, gear marks, \& skin abrasion } & $=0$ & $0.31(0.19-0.45)$ & $0.16(0.11-0.20)$ & $-0.16(-0.29--0.03)$ & $-50.00(-69.28--14.44)$ \\
\hline & $\leq 1$ & $0.89(0.83-0.94)$ & $0.79(0.72-0.86)$ & $-0.10(-0.19--0.01)$ & $-12.85(-21-49--2.40)$ \\
\hline Ecchymosis, poor exsanguination, \& skin abrasion & $\leq 1$ & $0.89(0.82-0.95)$ & $0.75(0.67-0.82)$ & $-0.14(0.23--0.04)$ & $-16.70(-26.73--5.37)$ \\
\hline \multicolumn{6}{|l|}{ Fillet index } \\
\hline \multirow{3}{*}{ Discoloration } & $=0$ & $0.34(0.27-0.43)$ & $0.17(0.11-0.22)$ & $-0.17(-0.28-0.07)$ & $-52.08(-72.48--26.02)$ \\
\hline & $=2$ & $0.04(0.02-0.08)$ & $0.13(0.08-0.18)$ & $0.09(0.03-0.16)$ & $208.72(41.57-805.96)$ \\
\hline & $\leq 1$ & $0.96(0.92-0.98)$ & $0.86(0.81-0.91)$ & $-0.09(-0.16--0.03)$ & $-11.27(-20.18--4.91)$ \\
\hline
\end{tabular}


1 Figure 1. Schematic showing a regular tow with direct haul-back (a) and a buffer tow (b).

2 Figure 2. Frequency of scores from the catch damage index for all cod caught with regular 3 haul-back.

4 Figure 3. Frequency of scores from the catch damage index for all cod that were buffer towed.

5 Figure 4. Frequency of scores from the fillet index for cod that were hauled-back directly.

6 Figure 5. Frequency of scores from the fillet index for cod that were buffer towed.

7 Figure 6. Results from the catch damage index showing the probability for cod to obtain a 8 score ranging from 0 to 3 for the four categories investigated. The bars represent $95 \%$ CIs. RT 9 denotes regular tows and BT denotes buffer tows. The scores that proved a significant difference in fish quality between RT and BT are highlighted in bold and black.

11 Figure 7. Results from the catch damage index showing the probability for cod to obtain a 12 score ranging from 0 to 3 for the four categories investigated for all categories combined as 13 well as for all possible combinations of two categories. The bars represent $95 \%$ CIs. RT 14 denotes regular tows and BT denotes buffer tows. The scores that proved a significant difference in fish quality between RT and BT are highlighted in bold and black.

Figure 8. Results from the catch damage index showing the probability for cod to obtain a score ranging from 0 to 3 for the four categories investigated for all possible combinations of three categories. The bars represent 95\% CIs. RT denotes regular tows and BT denotes buffer tows. The scores that proved a significant difference in fish quality between RT and BT are highlighted in bold and black.

Figure 9. Results from the fillet index showing the probability for cod to obtain a score ranging from 0 to 3 for the four categories investigated. The bars represent $95 \%$ CIs. RT denotes regular tows and BT denotes buffer tows. The scores that proved a significant difference in fish quality between RT and BT are highlighted in bold and black. Figure 10. (a) The fillets on the left represent a typical example of score 0 for the category "discoloration", whereas the two fillets on the right are a typical example of a score of 2. (b) shows an example of fillet gaping (arrows). 
FIG. 1

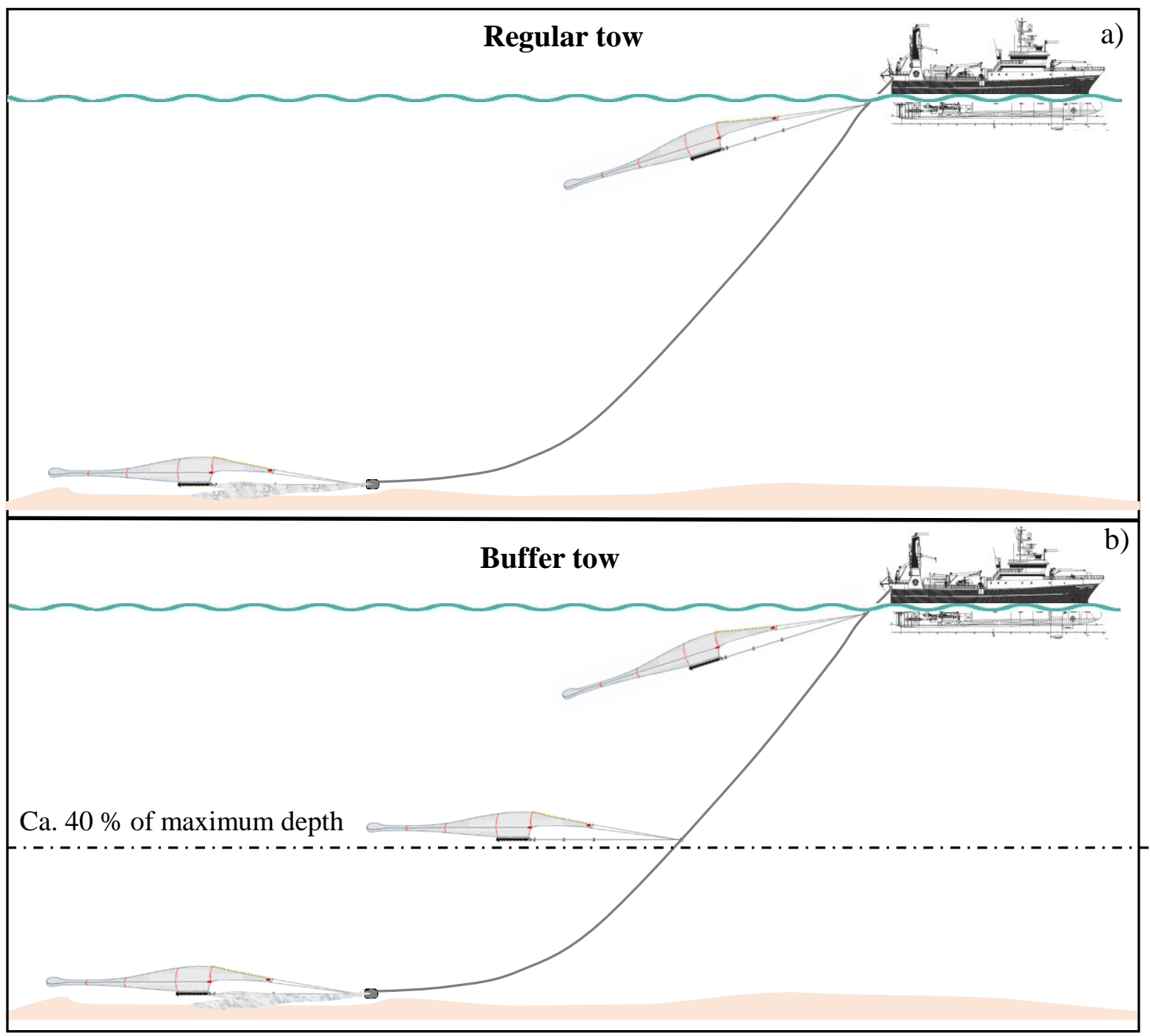

32 
FIG. 2
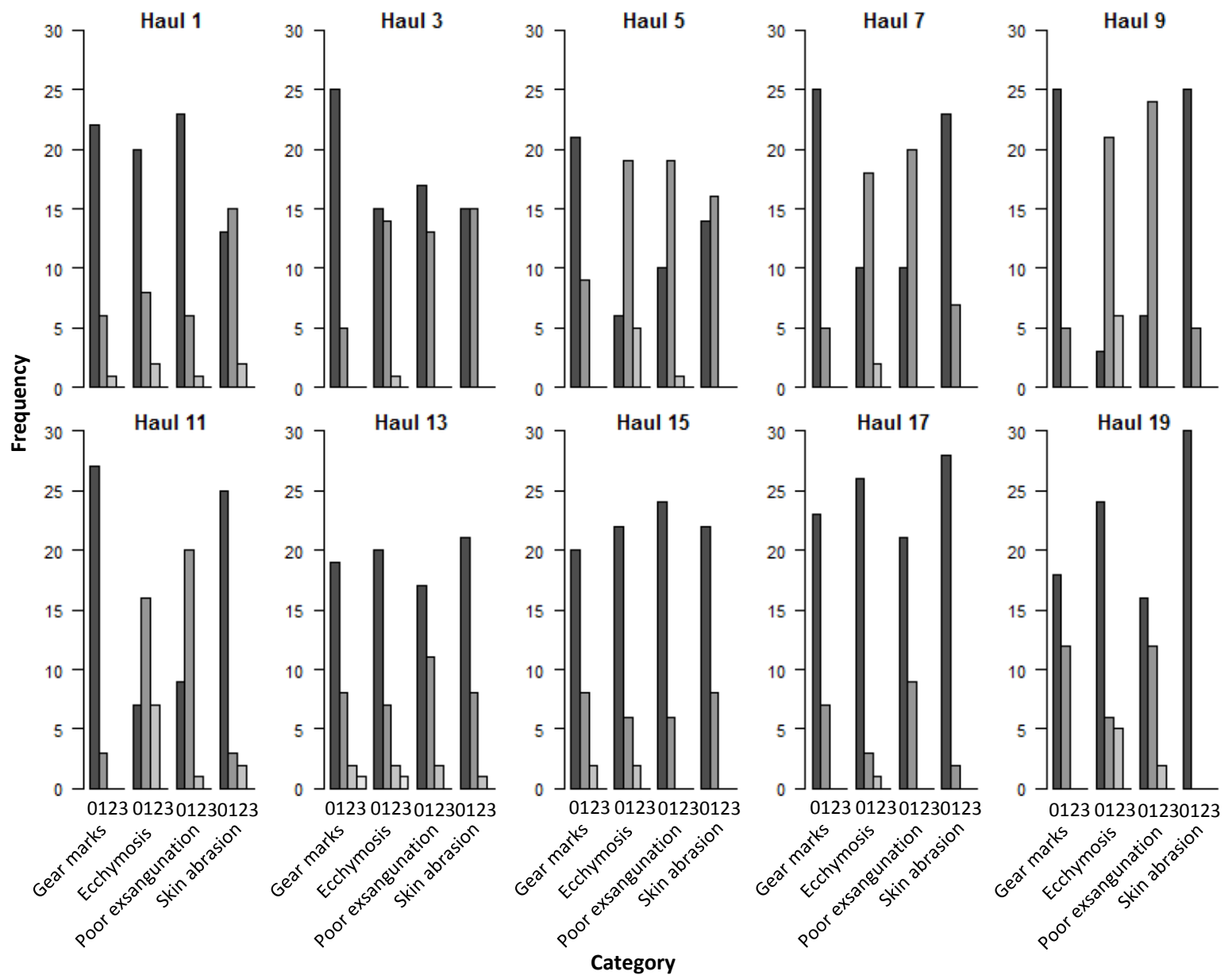
FIG. 3
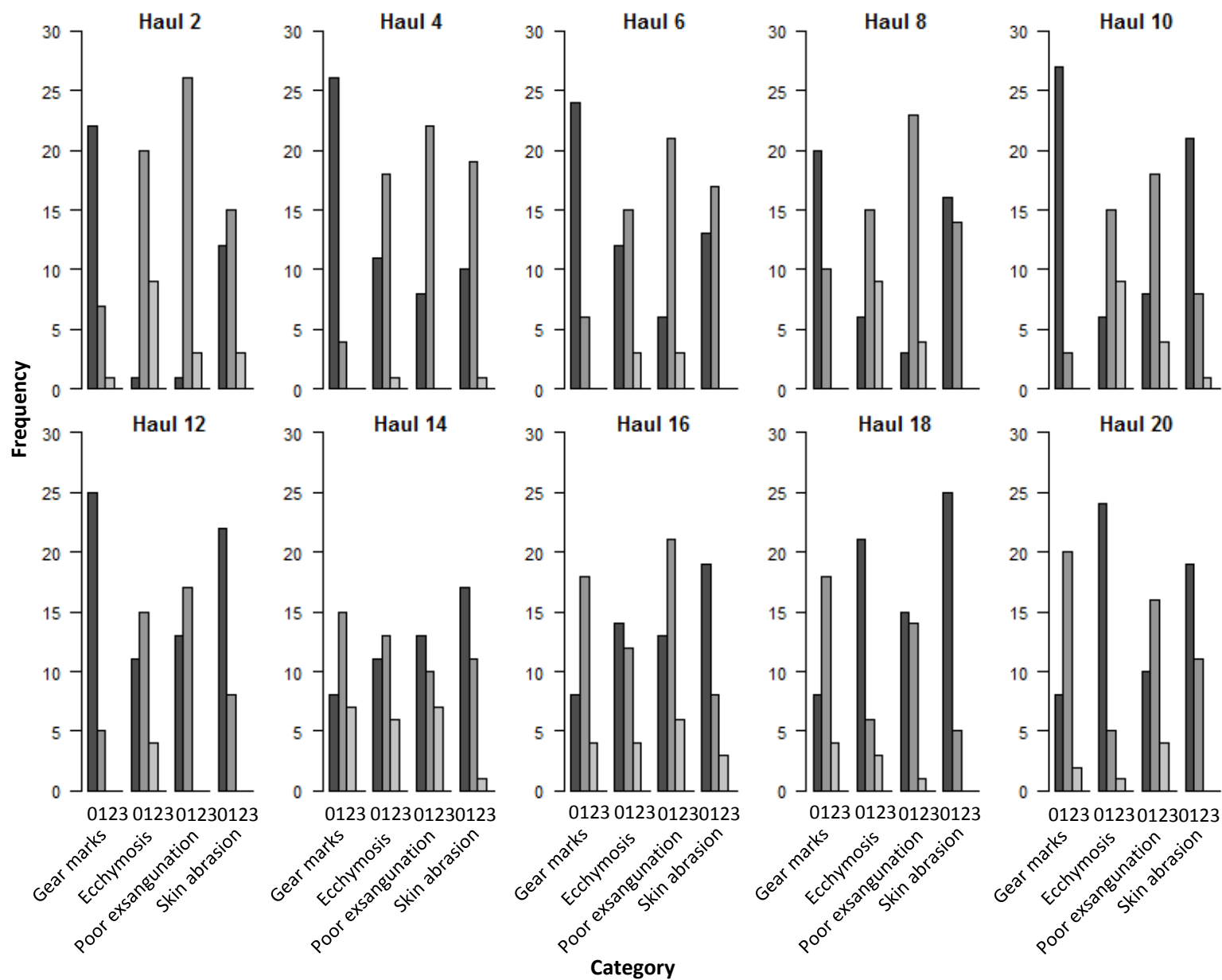
FIG. 4
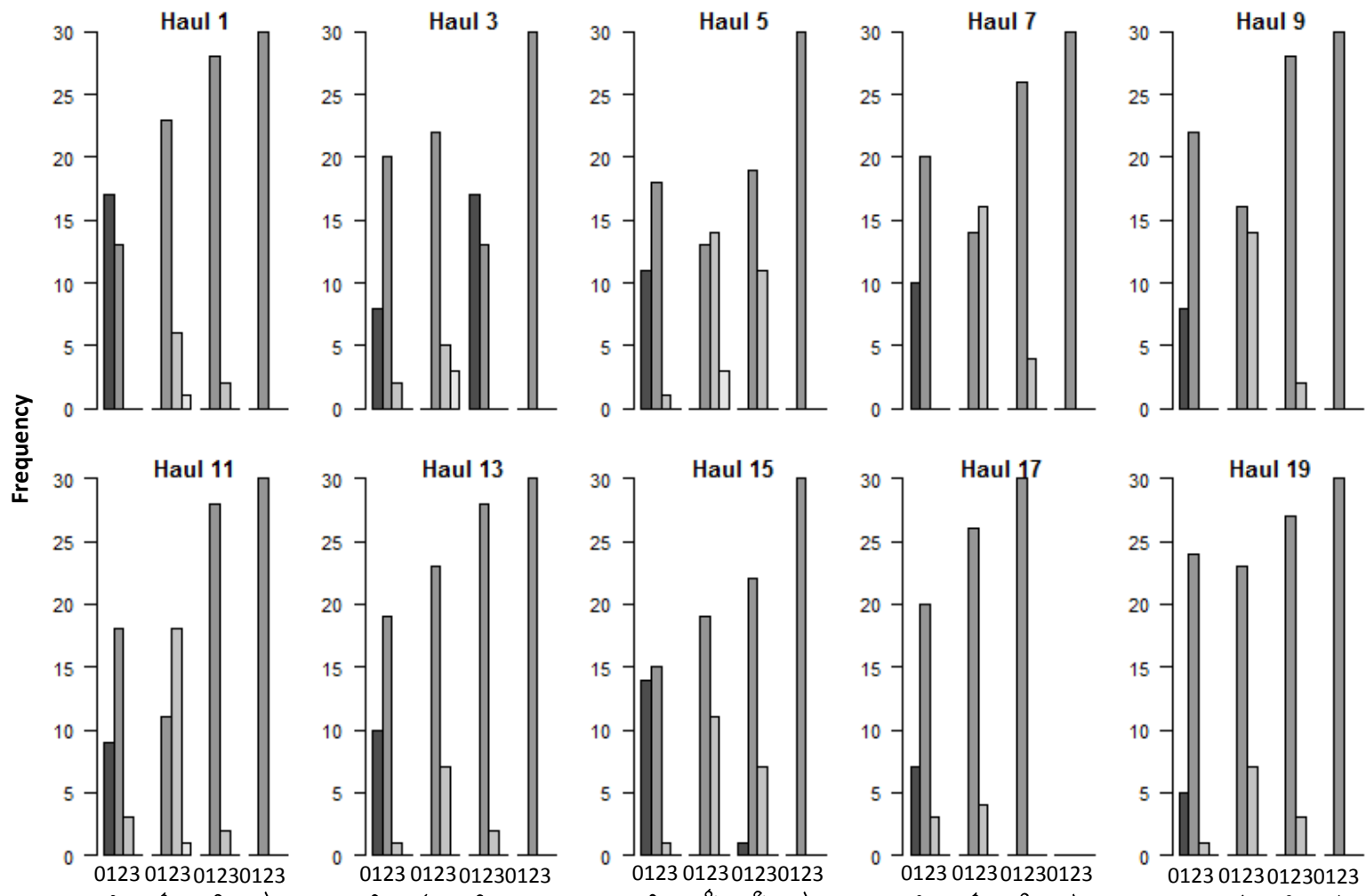

68
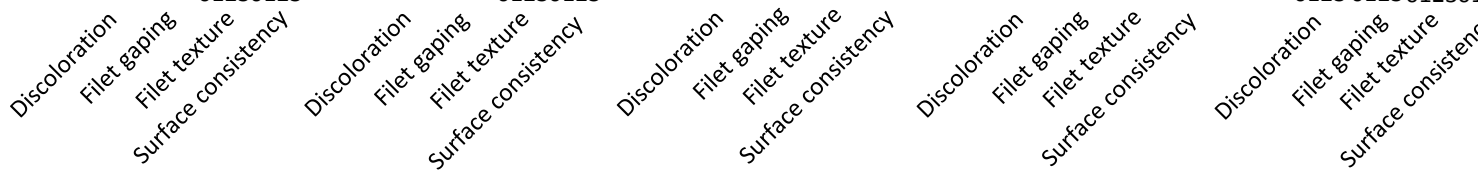
FIG. 5
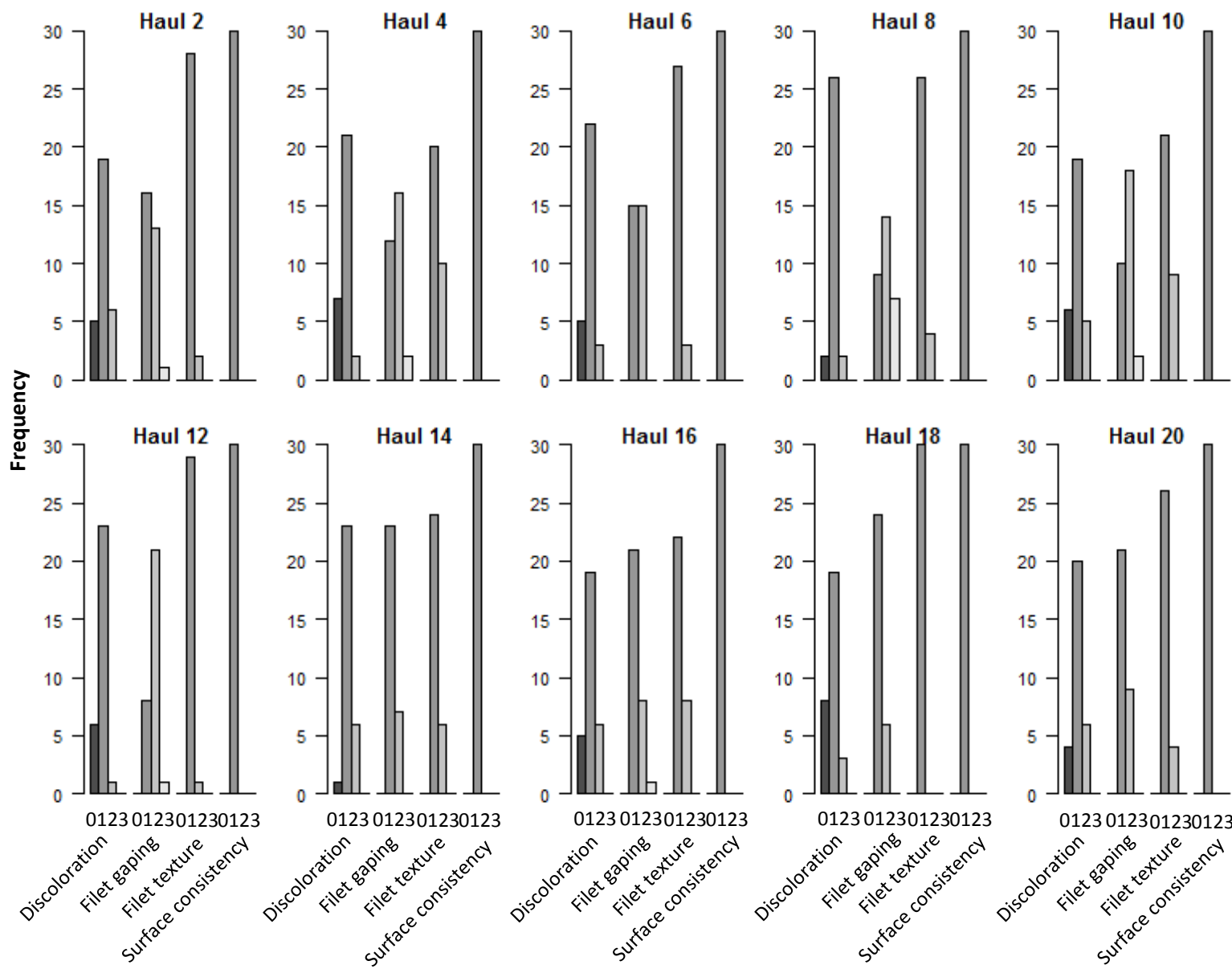

81
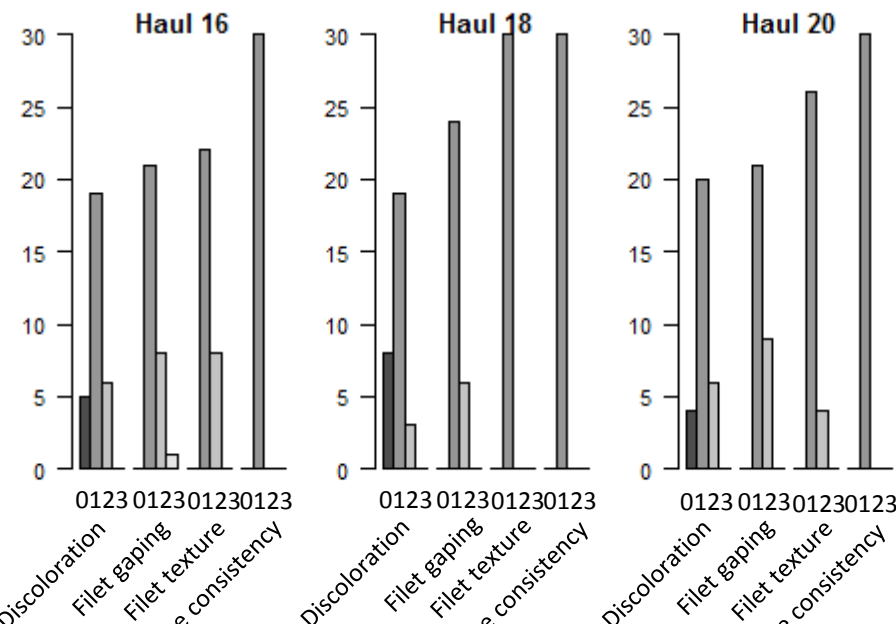

Category 
FIG. 6
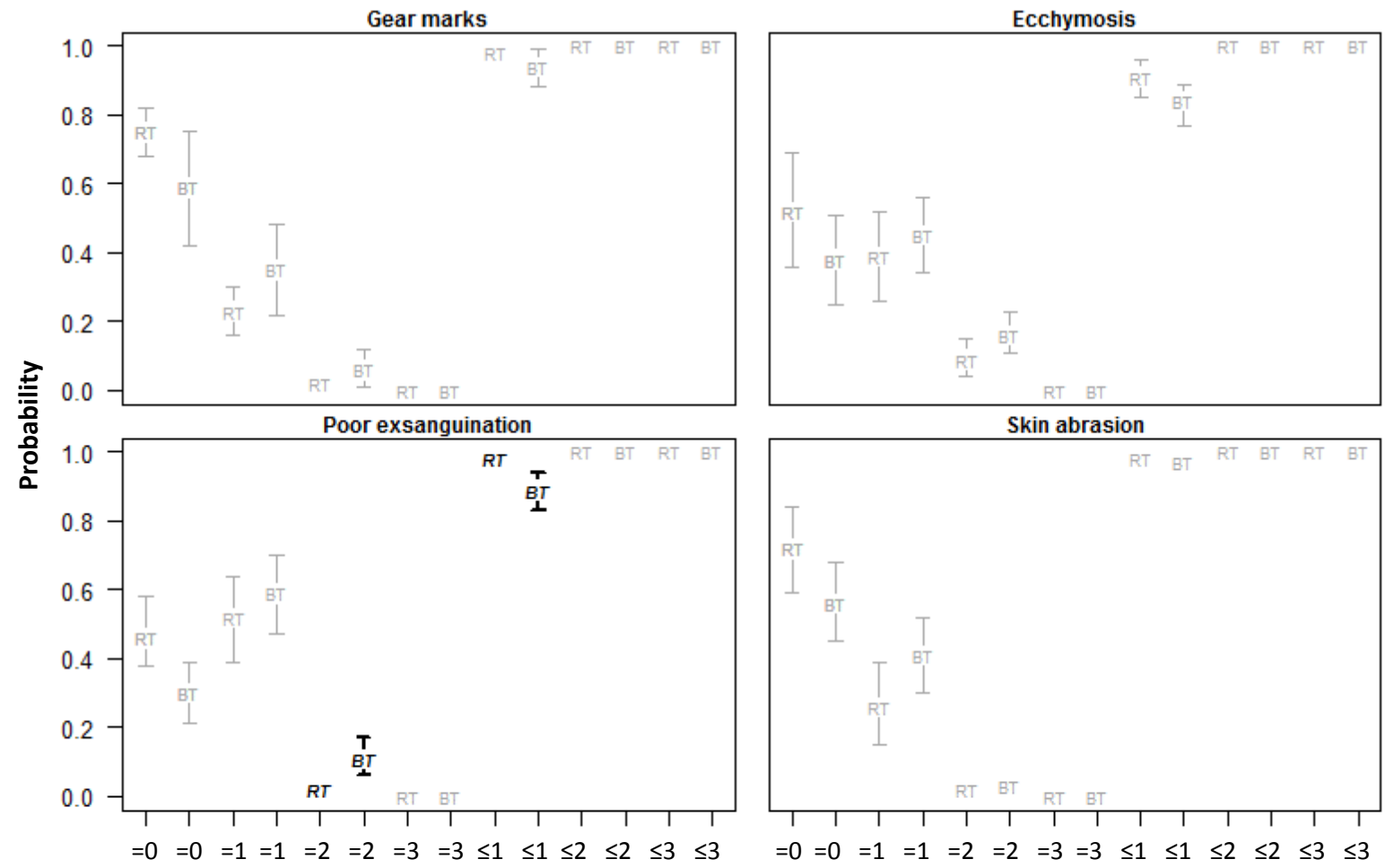

Index score 
FIG. 7
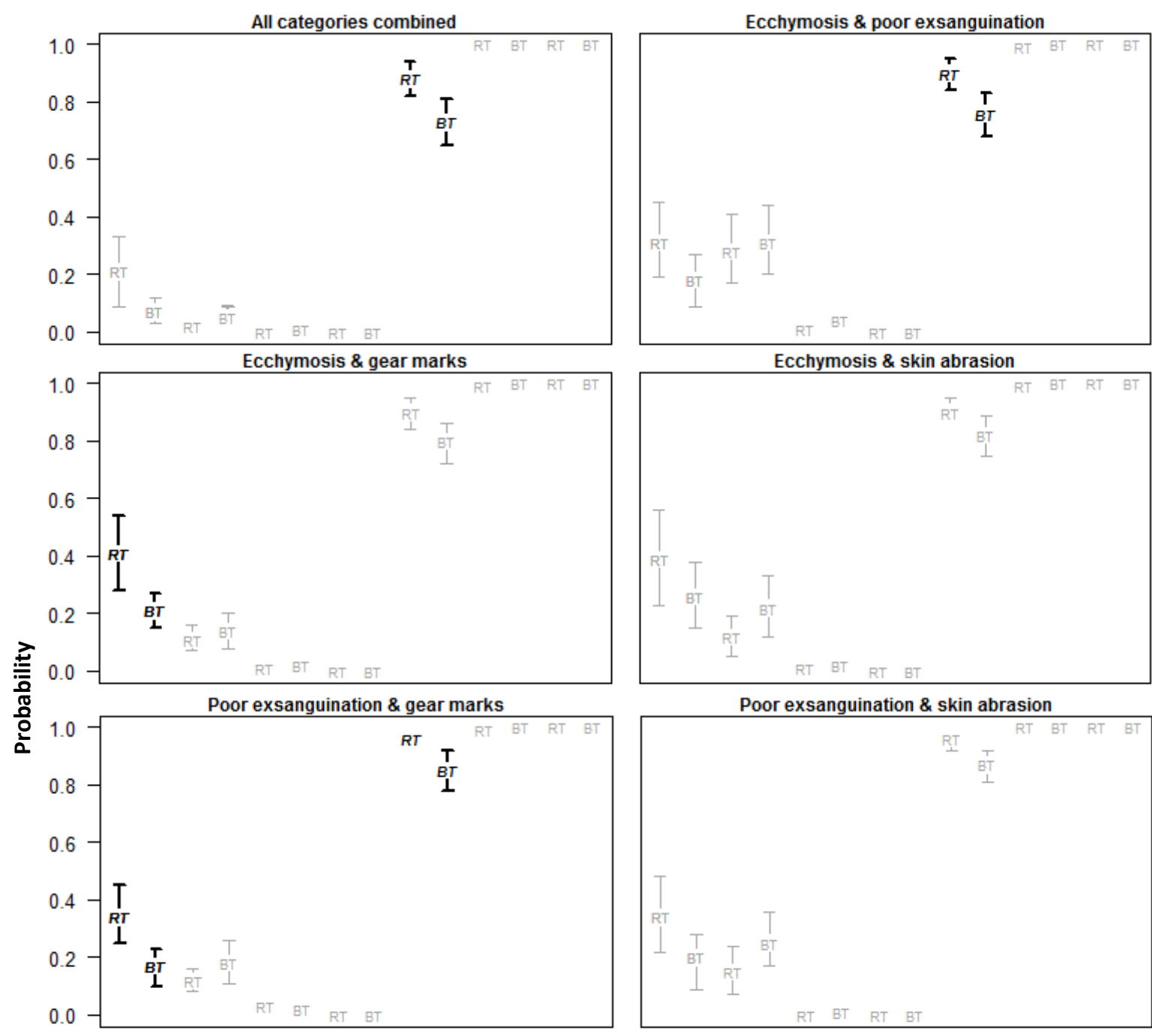

Ecchymosis \& skin abrasion

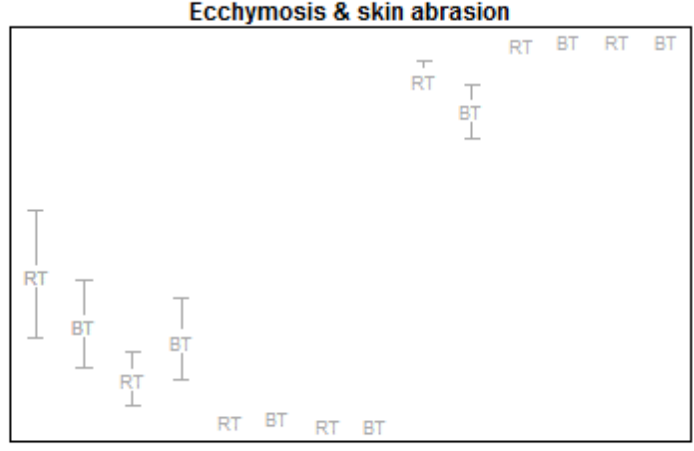

Poor exsanguination \& skin abrasion
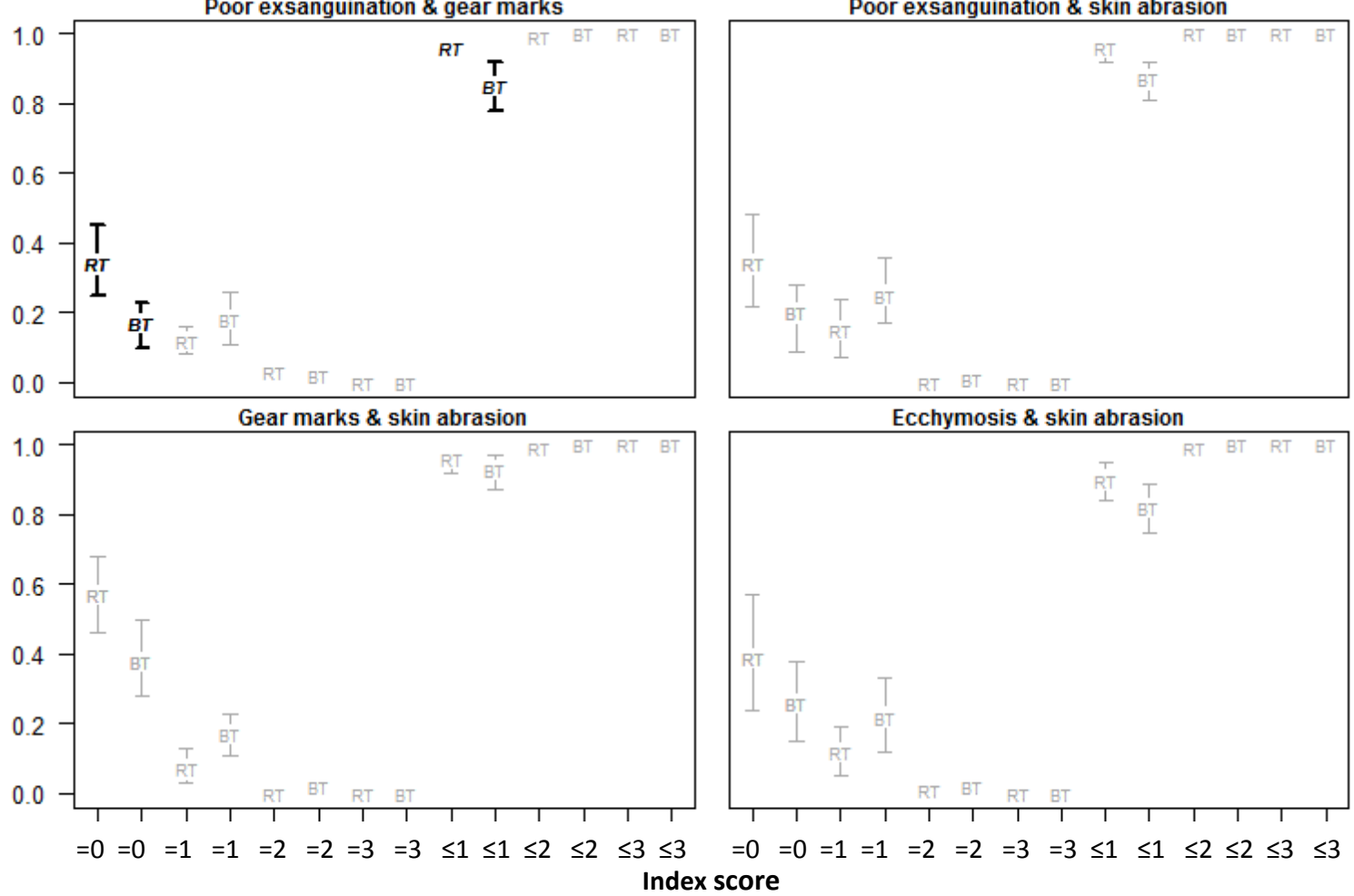

108 
FIG. 8
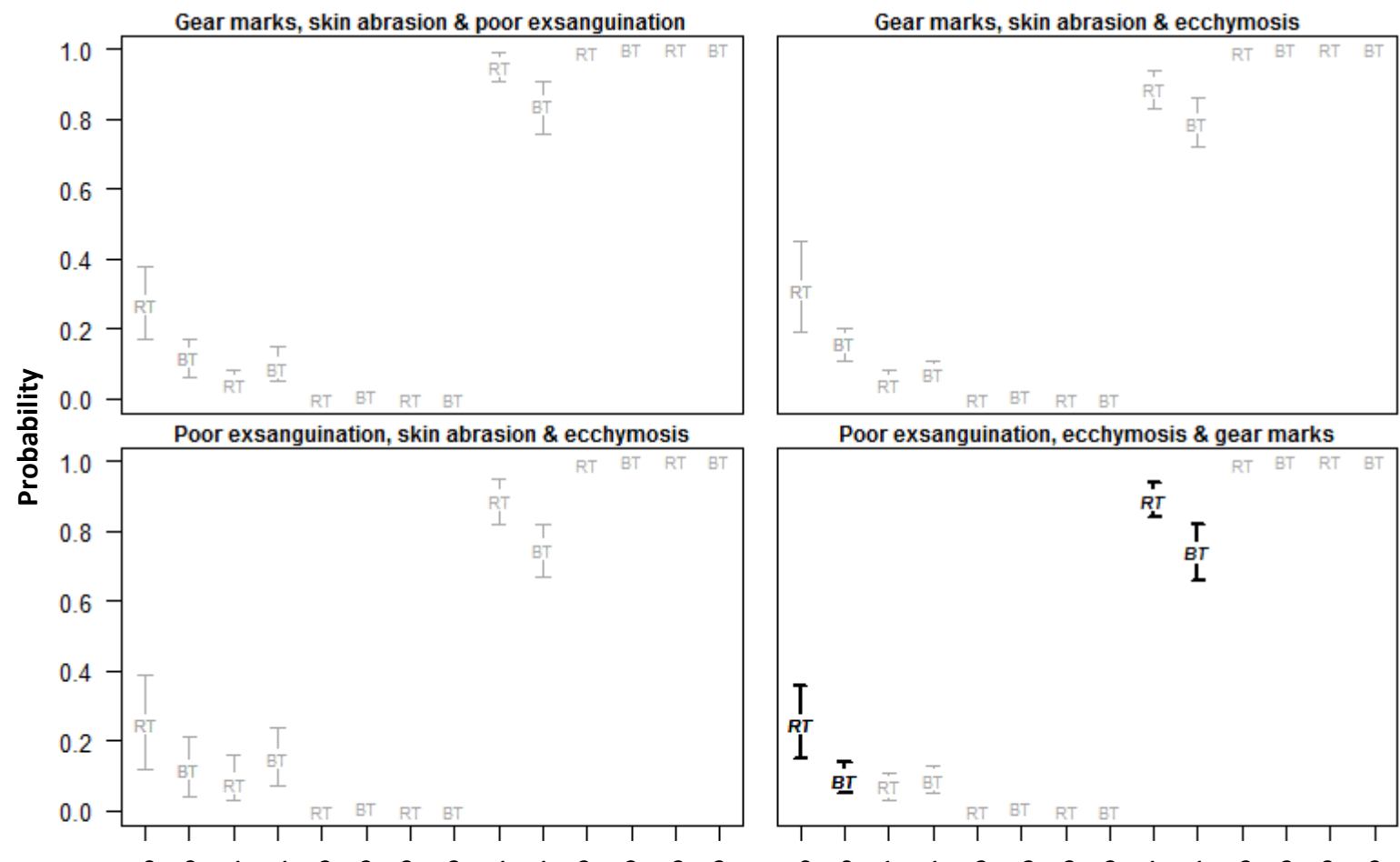

Poor exsanguination, ecchymosis \& gear marks
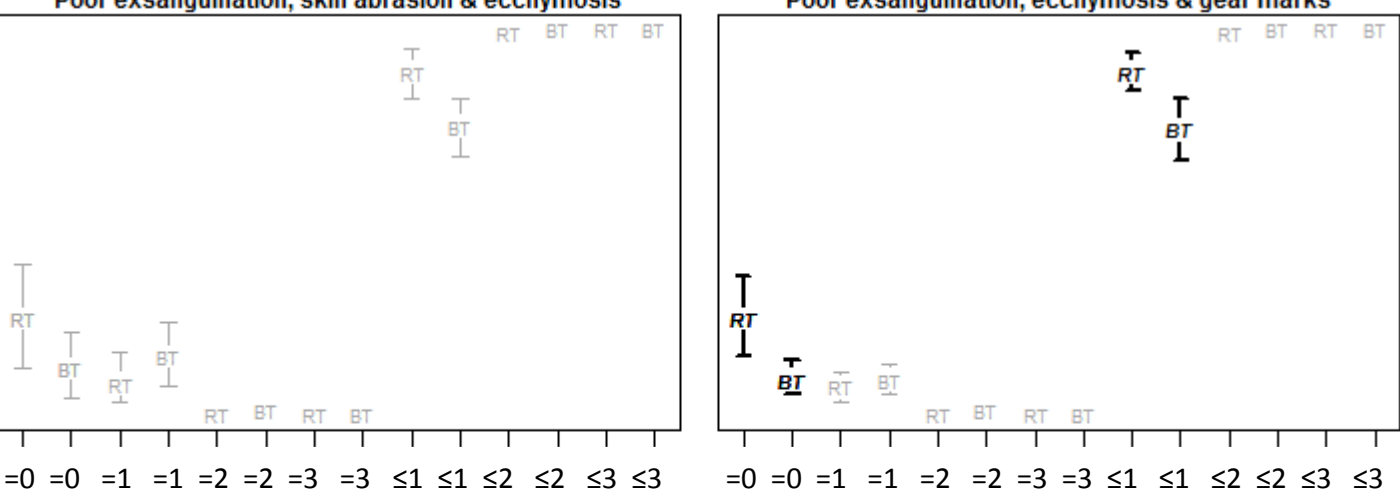

$=0=0=1=1=2=2=3=3 \leq 1 \leq 1 \leq 2 \leq 2 \leq 3 \leq 3$

Index score

112

113 FIG. 9
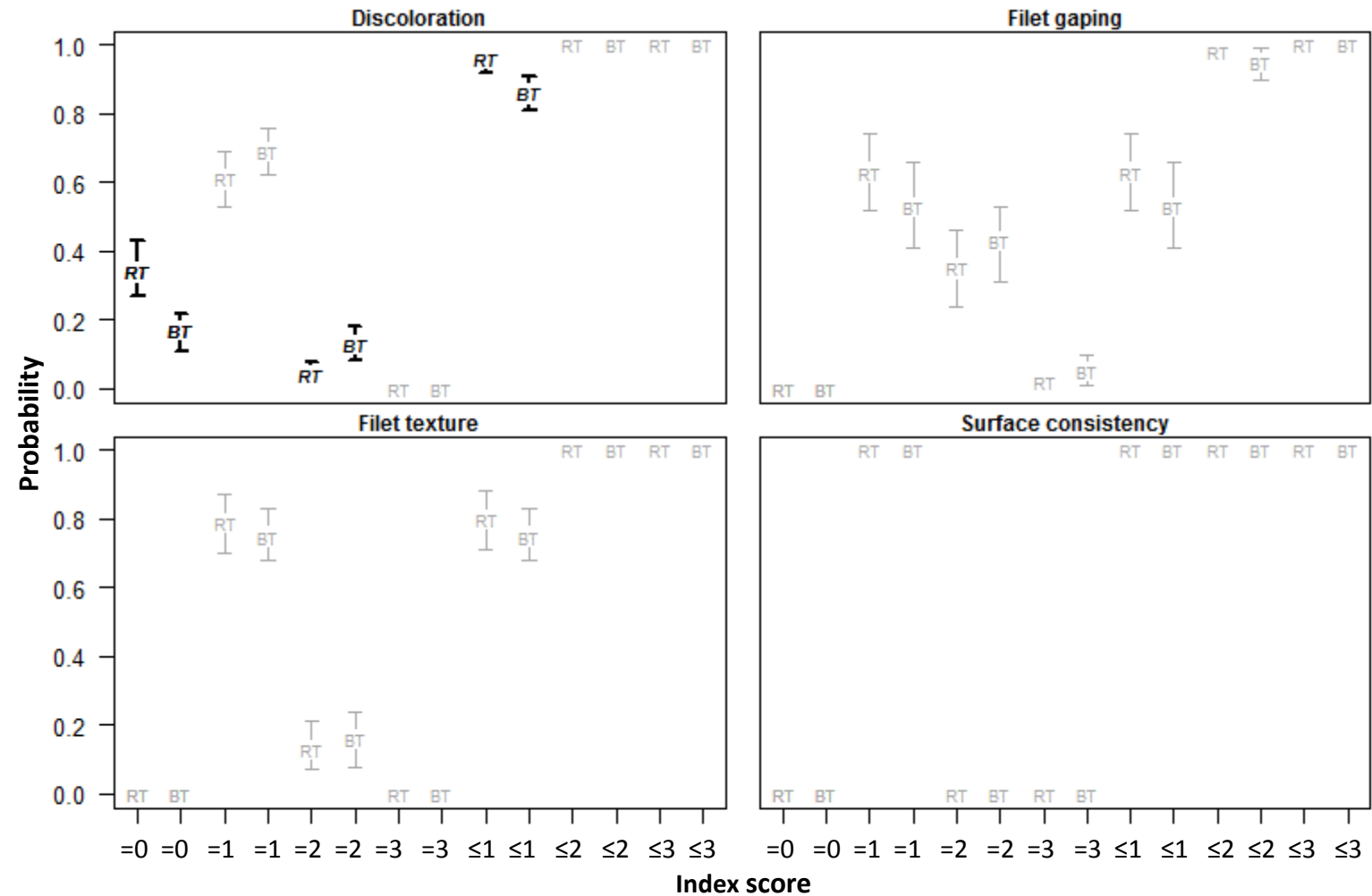
115 FIG. 10
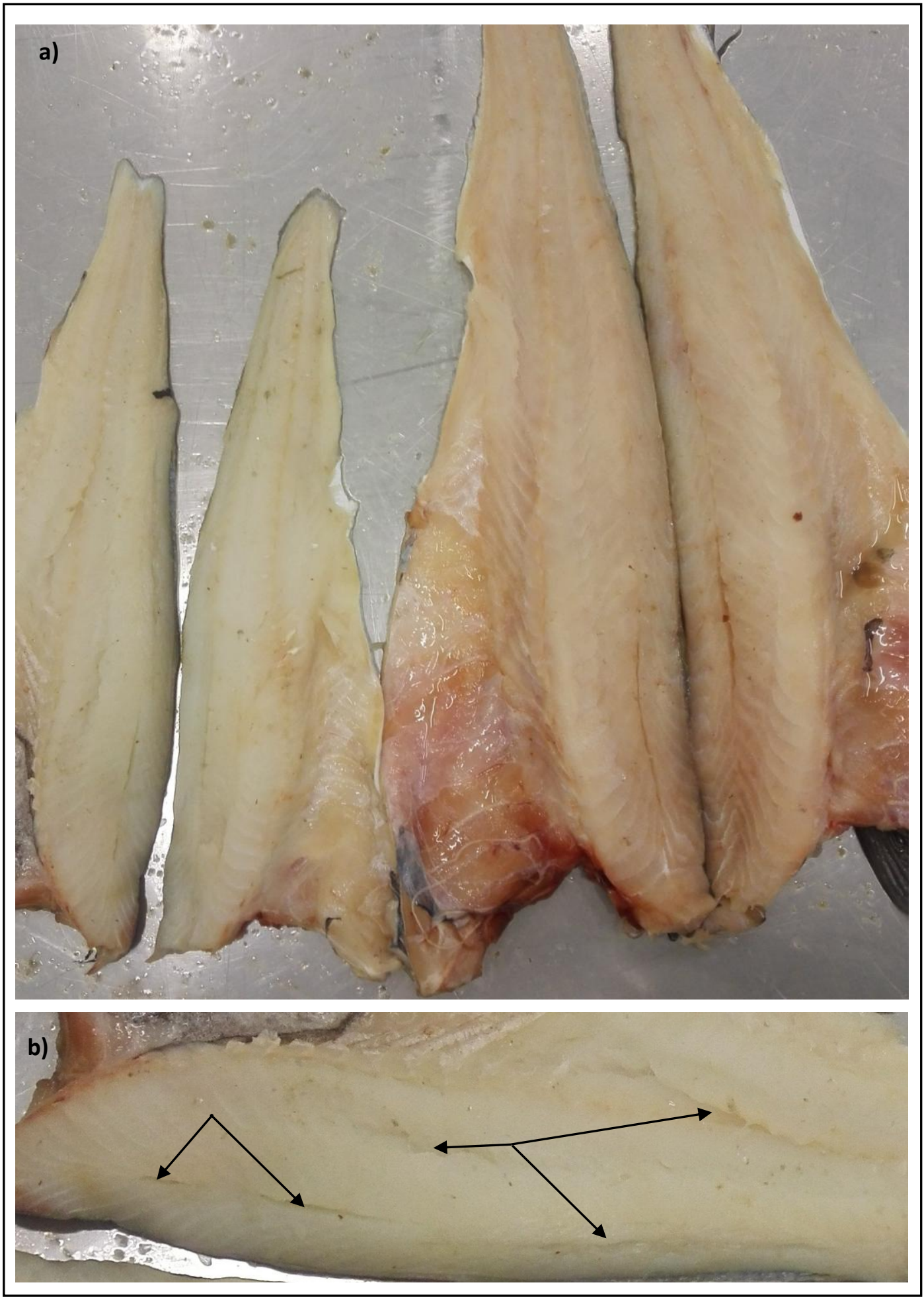